J. Lake Sci. (湖泊科学) , 2012, 24(5): 739-745

http: //www. jlakes. org. E-mail : jlakes@niglas.ac.cn

(c) 2012 by Journal of Lake Sciences

\title{
太湖浮游植物和各形态无机氮的时空分布特征”
}

\author{
冯露露, 李正鬼头 ${ }^{* *}$, 周 涛 \\ (南京大学环境学院污染控制与资源化研究国家重点实验室,南京 210093)
}

\begin{abstract}
摘 要: 为研究太湖浮游植物和各形态无机氮的时空分布特征及其相互关系, 于 2010 年 3 月至 2011 年 2 月在太湖全湖 范围内选取 9 个采样点进行每月采样分析, 结果表明: 太湖无机氮主要以硝态氮和铵氮形式存在,前者占 $76 \%$, 后者占 $22 \%$; 太湖北部靠近西北沿岸的湖区以及竺山湾的铵氮和亚硝态氮浓度通常要明显高于其他点位. 太湖各采样点 TIN (总 溶解性无机氮) 的季节变化趋势很相似,都表现为春季最高,夏秋季降低, 冬季又有所升高; 夏季北部湖区 TIN 降幅明显 大于南部, 使得前者 TIN/TSP ( 总溶解性磷) 远小于后者. 春季太湖南部的微囊藻复苏量大于北部, 但夏秋季微囊藻的暴 发主要发生在太湖北部, 此时微囊藻大暴发的点位 (如梅梁湾) 通常都伴随着很低的硝态氮浓度和 TIN/TSP, 使得这些点 位比其他地方更容易发生 N 限制; Chl.a/浮游植物的比值与浮游植物总数呈极显著负相关, 而与 TIN/TSP 的比值呈极显 著正相关, 这说明当藻类大量暴发而 TIN/TSP 下降时, 浮游植物单个细胞内的平均 Chl.a 含量会有所下降, 这种现象的原 因有待进一步研究; 绿藻、硅藻、裸藻和隐㩰在时空分布上有一定相似性, 而这四种藻与微囊藻则有较大差异.
\end{abstract}

关键词: 太湖;浮游植物;微囊藻;无机氮;时空分布

\section{Temporal and spatial distributions of phytoplankton and various forms of inorganic nitro- gen in Lake Taihu}

FENG Lulu, LI Zhengkui \& ZHOU Tao

(State Key Laboratory of Pollution Control and Resources Reuse, School of the Environment, Nanjing University, Nanjing 210093, P. R. China)

\begin{abstract}
Monthly whole-lake samplings (9 selected sites) were conducted from March 2010 to February 2011 to study the temporal and spatial distributions of phytoplankton and various forms of inorganic nitrogen and their relationships in Lake Taihu. Nitrate and ammonium were the major forms of inorganic nitrogen in the lake, which accounted for $76 \%$ and $22 \%$, respectively. Concentrations of ammonium and nitrite in the northwest coastal belt and Zhushan Bay in the northern lake were usually significantly higher than other sampling sites. Seasonal variations of total soluble inorganic nitrogen ( TIN) were very similar, in various sampling sites, which had generally a highest concentration in the spring, declined during summer-fall seasons, and then recovered in the winter. The summer TIN variations declined in the northern lake and was larger than these in the southern lake, which made the ratio of TIN:TSP in the northern lake much lower than that in the southern lake. Spring Microcystis spp. recruitment in the southern lake was more than that in the northern, but summer-fall blooms of Microcystis spp. mainly occurred in the northern lake, and the sites where Microcystis spp. greatly bloomed (e. g. Meiliang Bay) were usually accompanied with low levels of nitrite concentration and TIN:TSP ratio. The ratio of Chl.a:phytoplankton was significantly negative-correlated with phytoplankton number and positivecorrelated with the ratio of TIN:TSP, which indicated that the average content of Chl.a per phytoplankton cell declined with algae bloom and the ratio of TIN:TSP declines. The cause of this phenomenon needs further investigation. Temporal and spatial distributions of bacillariophyta, chlorophyta, euglenophyta and cryptophyta were similar to each other, but differed from that of Microcystis
\end{abstract} spp. .

Keywords: Lake Taihu; phytoplankton; Microcystis spp. ; inorganic nitrogen; temporal and spatial distributions

* 国家重点基础研究发展计划 “973” 项目 (2008CB418003) 和江苏省自然科学基金重点项目(BK2010056) 联合资助. 2012-01-17 收稿;2012-03-16 收修改稿. 冯露露, 男,1988 年生, 硕士研究生;E-mail : fengluluyx@ 163.com.

** 通信作者;E-mail:zhkuili@ nju. edu.cn. 
太湖位于苏、浙两省交界处,在长江三角洲的南部, 是中国东部近海区域最大的湖泊,也是中国的第三 大淡水湖. 近年来, 随着太湖周边人类活动的加剧, 大量营养盐通过各种途径进人太湖水体, 导致藻类和水 生植物增加、水质不断恶化,严重影响了太湖作为供水水源及周边居民的生产生活 ${ }^{[1]} .2007$ 年 5 月,无锡太 湖蓝藻水华危机事件 ${ }^{[2]}$ 使得太湖富营养化问题成为举世瞩目的环境问题 ${ }^{[3]}$.

氮和磷是植物和微生物的必需元素, 也是表征水体营养化程度的重要指标, 一直以来都被认为是水体 富营养化问题的主要影响因素. $\mathrm{Xu}$ 等 ${ }^{[4]}$ 研究表明,太湖中浮游植物在夏季表现出很强的氮限制, 因此控制 氮污染对于控制太湖富营养化问题有着重要作用. 溶解性无机氮是浮游植物吸收氮的主要形式,而水体中 的溶解性无机氮主要有硝态氮、铵态氮和亚硝态氮三种形态. 关于太湖溶解性无机氮和浮游植物的时空分 布以及其相互关系, 前人已经有所研究:如金相灿 等 $^{[5]}$ 研究了太湖东北部沉积物中的可溶性氮的季节性变 化,发现铵氮和硝态氮在夏季的释放量较大; 王秋娟等 ${ }^{[6]}$ 于 2009 年 10 月在太湖北部三个湖区进行采样并对 各形态氮的空间分布进行了分析, 发现水体中铵氮浓度为竺山湾 > 梅梁湾 > 贡湖湾, 而硝态氮浓度为贡湖 湾 $>$ 梅梁湾 $>$ 竺山湾; 杨柳等 ${ }^{[7]}$ 对太湖春季浮游植物群落对不同形态氮的吸收进行了研究, 发现大部分湖 区的浮游植物群落均优先吸收铵态氮. 以往对太湖溶解性无机氮以及浮游植物的时空分布研究大多集中在 太湖北部 ${ }^{[4-6,8-10]}$, 相对缺乏对南部的考察研究. 考虑到太湖作为一个大型浅水湖泊存在较大的空间差异性, 本文把太湖南部也纳人研究范围, 以便对不同湖区进行比照. 本研究在太湖全湖范围内选取 9 个采样点,从 2010 年 3 月到 2011 年 2 月每月采样一次, 目的在于利用所取得的原位数据分析各点位水体中浮游植物和 各形态无机氮的季节性变化特征及其相互关系,并探讨浮游植物所可能面临的营养盐限制, 为进一步控制 太湖富营养化提供参考.

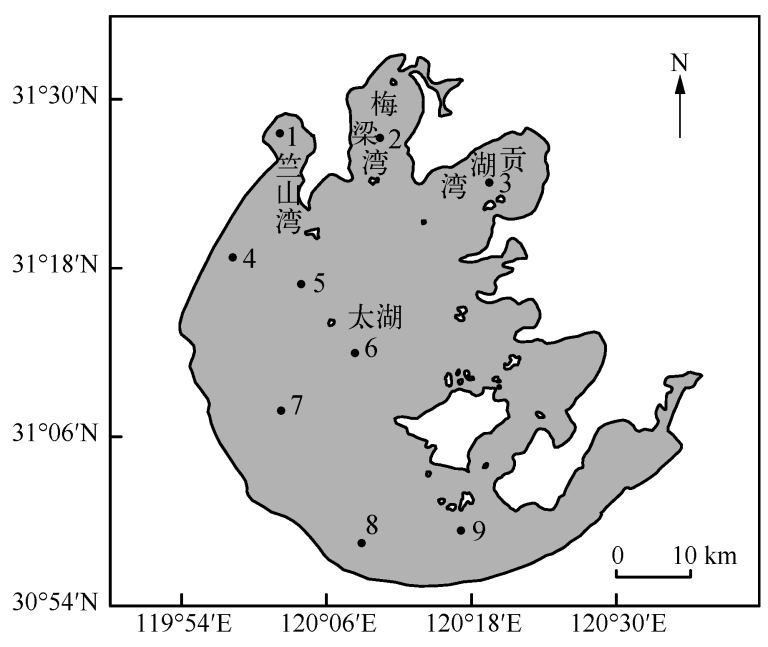

图 1 太湖采样点分布

Fig. 1 Location of sampling sites in Lake Taihu

\section{1 材料与方法}

\section{1 采样}

本研究在太湖北部设 5 个采样点 (点位 $1 \sim$ 5 ), 南部设 4 个采样点 (点位 6 9) (图 1). 从 2010 年 3 月到 2011 年 2 月,每月采集一次样 品并测定表底混合水样的水质 (表层水为水面 以下 $0 \sim 0.5 \mathrm{~m}$, 底层水为水底以上 $0 \sim 0.5 \mathrm{~m}$ ). 采样时测水温, 并取一部分水样用鲁哥试剂 (浓度约 $1.5 \%$ ) 固定, $48 \mathrm{~h}$ 后用于浮游植物的 群落组成分析.

\section{2 水化指标测定}

水样经 $0.45 \mu \mathrm{m}$ 滤膜过滤后, 用于测定总 溶解性无机氮 ( TIN) 、硝态氮 $\left(\mathrm{NO}_{3}^{-}-\mathrm{N}\right)$ 、铵氮 $\left(\mathrm{NH}_{4}^{+}-\mathrm{N}\right)$ 、亚硝态氮 $\left(\mathrm{NO}_{2}^{-}-\mathrm{N}\right)$ 以及总溶解性 磷( TSP), 其中 $\mathrm{NO}_{3}^{-}-\mathrm{N}$ 测定采用廄香草酚法和 紫外法, $\mathrm{NH}_{4}^{+}-\mathrm{N}$ 测定采用纳氏试剂比色法,

$\mathrm{NO}_{2}^{-}-\mathrm{N}$ 测定采用 $\mathrm{N}-$ ( 1-菜基) 乙二胺法, TIN 则为这三者之和, TSP 测定采用钿锑抗分光光度法. 另取一部分 未过滤的水样,采用冻融法 ${ }^{[11]}$ 测定叶绿素 a 浓度 (Chl.a).

\section{3 浮游植物分析}

利用血球计数板在显微镜放大 400 倍的视野中进行浮游植物的计数和鉴定. 浮游植物的鉴定方法参照 《淡水微型生物图谱 ${ }^{[12]}$ 以及 《中国淡水藻类: 系统、分类及生态 $\rangle^{[13]}$. 浮游植物的总丰度为蓝藻、绿藻、硅 藻、裸藻以及隐藻丰度之和. 


\section{2 结果}

\section{1 不同湖区浮游植物的季节变化}

春季太湖南部的微囊藻丰度总体上要多于太湖北部,靠近太湖南端的点位 8 在 2010 年的 $4 、 5$ 月份连续 出现微囊藻大量暴发 (大于 $100 \mathrm{cells} / \mu \mathrm{l}$ ) 的情形; 春季太湖北部浮游植物中非微囊藻 (即浮游植物总丰度与 微囊藻丰度的差值, 平均值为 $20 \mathrm{cells} / \mu \mathrm{l}$ ) 的丰度要大于太湖南部 (平均为 $7 \mathrm{cells} / \mu \mathrm{l}$ ), 前者微囊藻丰度所占 浮游植物总丰度的比例 (平均为 $52 \%$ ) 小于后者 (平均为 $81 \%$ ) ; 夏季和秋季微囊藻的暴发主要是发生在太 湖北部的梅梁湾 (点位 2 )、竺山湾 (点位 1 ) 以及西部沿岸地区 (点位 4 ), 而夏季贡湖湾 (点位 3 ) 和太湖南部 的微囊藻丰度相比于春季反而有所下降;夏、秋季节太湖北部的微囊藻丰度所占浮游植物总丰度的比例明 显增加, 平均达到 $84 \%$, 这不仅是因为微囊藻的大量增长, 也是因为其他种类浮游植物的总丰度在此期间有 所降低 ( 从春季的 $20 \mathrm{cells} / \mu \mathrm{l}$ 下降至夏、秋季的 $9 \mathrm{cells} / \mu \mathrm{l}$ ) ; 在冬季采样期间,各点位都没有发现微囊藻 大量暴发,太湖总体微囊藻丰度有所下降,而其他种类的浮游植物总丰度反而比秋季有所升高 (竺山 湾除外) (图 2).

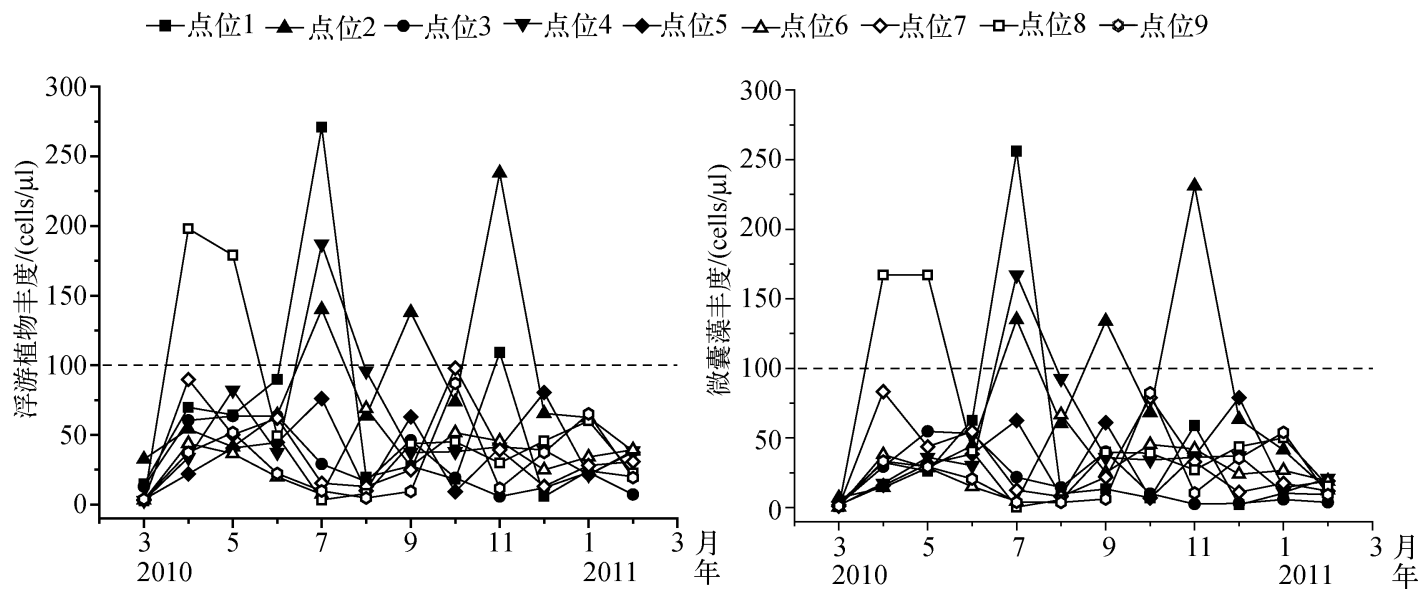

图 2 太湖各点位浮游植物和微囊藻的季节性变化

Fig. 2 Seasonal variations of phytoplankton and Microcystis spp. in each site of Lake Taihu

\section{2 不同湖区无机氮的季节变化}

太湖不同湖区各采样点硝态氮浓度的季节变化趋势总体上有着很强的相似性,都表现为春季最高, 夏、 秋季有所降低,冬季又升高 (图 3); 春季太湖北部 (各点平均为 $2.87 \mathrm{mg} / \mathrm{L}$ ) 的 $\mathrm{NO}_{3}^{-}-\mathrm{N}$ 浓度总体上略低于太 湖南部 (各点平均为 $3.11 \mathrm{mg} / \mathrm{L}$ ) ; 北部各湾区之间的硝态氮差别不大, 但贡湖湾比竺山湾和梅梁湾略低, 南 部湖区中点位 6 的 $\mathrm{NO}_{3}^{-}-\mathrm{N}$ 浓度明显高于其他各点; 到了夏季,太湖北部各点的 $\mathrm{NO}_{3}^{-}-\mathrm{N}$ 浓度均大幅下降 (各 点平均浓度为 $1.30 \mathrm{mg} / \mathrm{L}$ ), 而太湖南部除了点位 6 之外其他各点的 $\mathrm{NO}_{3}^{-}-\mathrm{N}$ 浓度下降幅度都很小, 此时太湖 南部 (各点平均浓度为 $2.30 \mathrm{mg} / \mathrm{L}$ ) 的 $\mathrm{NO}_{3}^{-}-\mathrm{N}$ 浓度明显高于北部; 秋季太湖南部各点的 $\mathrm{NO}_{3}^{-}-\mathrm{N}$ 浓度急剧下 降,达到平均 $0.57 \mathrm{mg} / \mathrm{L}$ 的全年最低水平, 此时太湖北部的 $\mathrm{NO}_{3}^{-}-\mathrm{N}$ 依然维持在较低浓度,但各湾区之间出现 较大差异, 表现为竺山湾 > 贡湖湾 > 梅梁湾 (仅为 $0.33 \mathrm{mg} / \mathrm{L}$ ) ; 冬季太湖北部的 $\mathrm{NO}_{3}^{-}-\mathrm{N}$ 浓度有较大幅度升 高, 而南部各点虽然也有上升但幅度较小, 此时太湖北部的 $\mathrm{NO}_{3}^{-}-\mathrm{N}$ 浓度 (各点平均为 $1.90 \mathrm{mg} / \mathrm{L}$ ) 高于南部 (各点平均为 $1.01 \mathrm{mg} / \mathrm{L}$ ). 太湖不同湖区各采样点 $\mathrm{TIN}$ 的季节变化趋势与 $\mathrm{NO}_{3}^{-}-\mathrm{N}$ 基本相同,也表现为春季 最高,夏、秋季有所降低,冬季又有所升高. 全年平均而言, $\mathrm{NO}_{3}^{-}-\mathrm{N}$ 占 $\mathrm{TIN}$ 的 $76 \%, \mathrm{NH}_{4}^{+}-\mathrm{N}$ 占 $22 \%, \mathrm{NO}_{2}^{-}-\mathrm{N}$ 占 $2 \%$.

太湖不同点位 $\mathrm{NH}_{4}^{+}-\mathrm{N}$ 的季节变化存在差异, 但大部分点位都在春季达到最高值. 在春季的每月采样中 太湖有较多点位的 $\mathrm{NH}_{4}^{+}-\mathrm{N}$ 超过 $1 \mathrm{mg} / \mathrm{L}$, 总体而言北部的 $\mathrm{NH}_{4}^{+}-\mathrm{N}$ 浓度 (各点平均为 $0.88 \mathrm{mg} / \mathrm{L}$ ) 要高于南部 

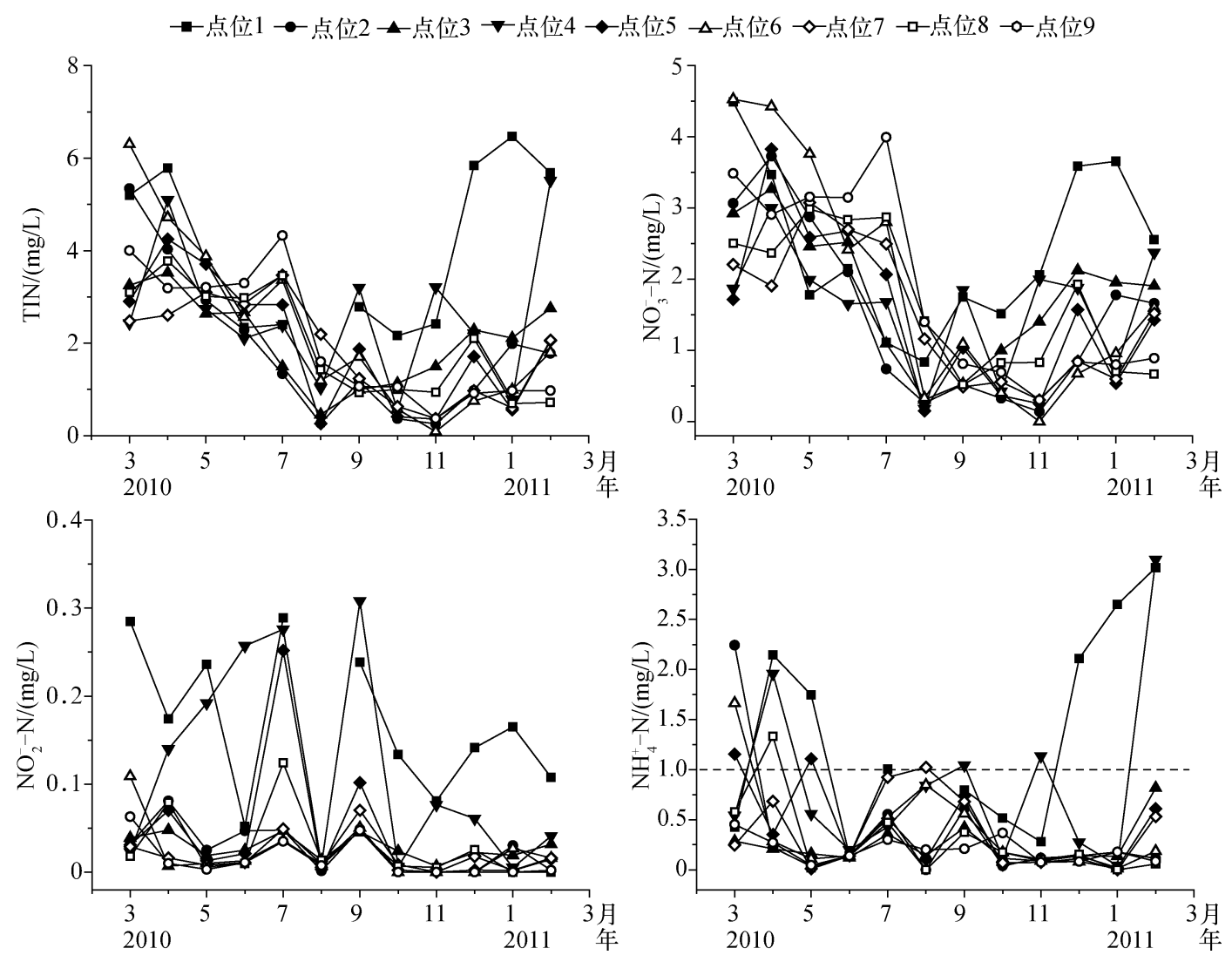

图 3 太湖各点位溶解性无机氮的季节性变化

Fig. 3 Seasonal variations of dissolved inorganic nitrogen in each site of Lake Taihu

(各点平均为 $0.48 \mathrm{mg} / \mathrm{L}$ ), 北部各湾区之间的 $\mathrm{NH}_{4}^{+}-\mathrm{N}$ 浓度差别较大, 表现为竺山湾 > 梅梁湾 > 贡湖湾. 夏、 秋季节, 太湖总体的 $\mathrm{NH}_{4}^{+}-\mathrm{N}$ 浓度有所下降, 其中北部湖区各点位 (除了贡湖湾) 在夏季的下降幅度都很大. 冬季太湖北部的竺山湾 $\mathrm{NH}_{4}^{+}-\mathrm{N}$ 浓度明显回升, 达到全年最高水平, 而南部各点的 $\mathrm{NH}_{4}^{+}-\mathrm{N}$ 浓度在此时则是 全年最低. 太湖各季节 $\mathrm{NO}_{2}^{-}-\mathrm{N}$ 的浓度都比较低, 总体上春、夏季要高于秋、冬季. 全年总体而言,太湖北部靠 近西北沿岸 (点位 4) 的湖区以及竺山湾的 $\mathrm{NH}_{4}^{+}-\mathrm{N}$ 和 $\mathrm{NO}_{2}^{-}-\mathrm{N}$ 浓度要高于其他点位.

\section{3 浮游植物和无机氮的相关性分析}

浮游植物总丰度与微囊藻、绿藻、硅藻以及隐藻丰度呈极显著正相关, 其中与微囊藻丰度的相关系数最 大 $(r=0.977, P<0.001)$, 浮游植物总丰度与裸藻丰度的相关性不显著. 浮游植物总丰度与 Chl. a 呈极显著 正相关, 但相关系数不大 $(r=0.300, P<0.001)$. 绿藻、硅藻、裸藻和隐藻丰度彼此之间都存在极显著的相关 性, 但这四种藻与微囊藻丰度的相关性则不显著. 浮游植物总丰度、微囊藻丰度以及 Chl. a 都与水温呈显著 正相关, 但其他四种藻与温度的相关性不显著. 浮游植物总丰度、微囊藻丰度以及 $\mathrm{Chl} . \mathrm{a}$ 都与 $\mathrm{NO}_{2}^{-}-\mathrm{N}$ 呈显著 正相关. 微囊藻丰度与硝态氮呈显著负相关 $(r=-0.188, P<0.05)$, 与 $\mathrm{NH}_{4}^{+}-\mathrm{N}$ 则无显著相关性. 浮游植物 总丰度以及微囊藻丰度都与 TIN/TSP 的比值呈极显著负相关. Chl.a/浮游植物总丰度的比值 (即单个细胞内 的 Chl.a 含量) 与浮游植物总丰度、微囊藻丰度以及 TIN/TSP 的比值呈极显著正相关. 绿藻与各形态无机氮 都呈极显著正相关, 硅藻与 TIN 、 $\mathrm{NO}_{3}^{-}-\mathrm{N}$ 以及 $\mathrm{NO}_{2}^{-}-\mathrm{N}$ 呈显著正相关 (表 1). 此外, $\mathrm{NH}_{4}^{+}-\mathrm{N}$ 与 $\mathrm{NO}_{3}^{-}-\mathrm{N}(r=$ $0.328, P<0.001) 、 \mathrm{NH}_{4}^{+}-\mathrm{N}$ 与 $\mathrm{NO}_{2}^{-}-\mathrm{N}(r=0.423, P<0.00001)$ 以及 $\mathrm{NO}_{3}^{-}-\mathrm{N}$ 与 $\mathrm{NO}_{2}^{-}-\mathrm{N}(r=0.288, P<0.01)$ 彼此之间都呈极显著正相关. 


\section{3 讨论}

\section{1 不同湖区浮游植物的季节变化及其原因分析}

2010 年 3 月- 2011 年 2 月, 太湖北部和南部的浮游植物以及微囊藻的季节变化存在很大差别. 南部湖 区各点位春季水体浮游植物中非微囊藻的部分比北部要少, 但其微囊藻丰度总体上比北部湖区多, 而且靠 近太湖南端的点位 8 在 2010 年的 $4 、 5$ 月份连续出现微囊藻大量暴发 (大于 $100 \mathrm{cells} / \mu \mathrm{l}$ ) 的情形, 这可能是 因为微囊藻越冬之后的春季复苏更多是发生在太湖的南部. 为什么南部湖区的春季复苏量更大呢? 该现象 可能并非由于南部湖区在营养盐方面存在优势, 因为春季两湖区的 TIN 含量基本相同, 虽然北部湖区的 $\mathrm{NO}_{3}^{-}-\mathrm{N}$ 含量略微低于南部湖区, 但其 $\mathrm{NH}_{4}^{+}-\mathrm{N}$ 和 $\mathrm{NO}_{2}^{-}-\mathrm{N}$ 含量都要高于南部, 而且以往的研究表明太湖北部 的磷含量也通常更高 ${ }^{[14]}$. 季健等 ${ }^{[15]}$ 对 2007-2008 年太湖越冬蓝藻的空间分布进行了研究, 发现该年冬季 越冬蓝藻主要分布在西太湖和南太湖. 因此, 南部湖区微囊藻春季复苏量大很有可能是因为其越冬微囊藻 的数量多,这和太湖冬季盛行的西北风以及蓝藻的输移存在一定关系.

表 1 太湖各水质指标的相关性分析

Tab. 1 Correlation analysis of each water quality index of Lake Taihu

\begin{tabular}{|c|c|c|c|c|c|c|c|c|}
\hline 相关因子 & $\begin{array}{c}\text { 浮游植物 } \\
\text { 总丰度 }\end{array}$ & Chl.a & $\begin{array}{l}\text { Chl.a/浮游 } \\
\text { 植物总丰度 }\end{array}$ & $\begin{array}{c}\text { 微囊藻 } \\
\text { 丰度 }\end{array}$ & $\begin{array}{l}\text { 绿藻 } \\
\text { 丰度 }\end{array}$ & $\begin{array}{l}\text { 硅藻 } \\
\text { 丰度 }\end{array}$ & $\begin{array}{l}\text { 裸藻 } \\
\text { 丰度 }\end{array}$ & $\begin{array}{l}\text { 隐藻 } \\
\text { 丰度 }\end{array}$ \\
\hline 浮游植物总丰度 & 1 & & & & & & & \\
\hline Chl.a & $0.300^{* *}$ & 1 & & & & & & \\
\hline Chl.a/浮游植物总丰度 & $-0.302 * *$ & $0.314^{* *}$ & 1 & & & & & \\
\hline 微囊藻丰度 ～～～～～ & $0.977^{* * *}$ & $0.298^{* *}$ & $-0.271^{* *}$ & 1 & & & & \\
\hline 绿藻丰度 & $0.279^{* *}$ & $0.166^{*}$ & -0.101 & 0.108 & 1 & & & \\
\hline 硅藻丰度 & $0.311^{* *}$ & 0.011 & $-0.246^{* *}$ & 0.117 & $0.596^{* * *}$ & 1 & & \\
\hline 裸藻丰度 & -0.002 & 0.023 & 0.025 & -0.076 & $0.258^{* *}$ & $0.243^{* *}$ & 1 & \\
\hline 隐藻丰度 & $0.237^{* *}$ & -0.011 & -0.045 & 0.157 & $0.411^{* * * *}$ & $0.263^{* *}$ & $0.420^{* * *}$ & 1 \\
\hline TIN & -0.065 & 0.031 & $0.184^{*}$ & -0.144 & $0.463^{* * *}$ & $0.219^{*}$ & 0.063 & 0.113 \\
\hline $\mathrm{NO}_{3}^{-}-\mathrm{N}$ & -0.119 & -0.095 & $0.180^{*}$ & $-0.188^{*}$ & $0.346^{* * *}$ & $0.205^{*}$ & 0.093 & 0.062 \\
\hline $\mathrm{NO}_{2}^{-}-\mathrm{N}$ & $0.278^{* *}$ & $0.249^{* *}$ & 0.029 & $0.218^{*}$ & $0.359^{* * * *}$ & $0.249^{* *}$ & 0.076 & $0.244 * *$ \\
\hline $\mathrm{NH}_{4}^{+}-\mathrm{N}$ & 0.027 & $0.213^{*}$ & 0.110 & -0.030 & $0.434^{* * * *}$ & 0.124 & -0.026 & 0.129 \\
\hline TIN/TSP & $-0.262^{* *}$ & 0.005 & $0.424^{* * *}$ & $-0.250^{* *}$ & -0.056 & -0.134 & 0.034 & -0.079 \\
\hline 温度 & $0.248^{* *}$ & $0.206^{*}$ & -0.088 & $0.282^{* *}$ & -0.112 & -0.068 & 0.025 & -0.081 \\
\hline
\end{tabular}

注: $n=100, *$ 表示 $P<0.05, * *$ 表示 $P<0.01, * * *$ 表示 $P<0.001$.

夏秋季节太湖微囊藻的大量生长和暴发主要集中在北部的梅梁湾、竺山湾以及靠近西北沿岸的湖区, 而南部湖区的夏季微囊藻丰度相比春季不但没有增加反而有所减少, 原来发生春季大暴发的点位 8 夏季微 囊藻丰度也非常少 (平均仅有 $15 \mathrm{cells} / \mu \mathrm{l}$ ). 由此可见,特定湖区蓝藻夏、秋季暴发量的大小并非取决于该湖 区春季复苏量的大小. 蓝藻在季风影响下的漂移聚集可能是该现象的原因之一, 如杨清心 ${ }^{[16]}$ 对太湖水华进 行考察,认为太湖夏季盛行的东南风是促使西北湖区形成严重水华的主要原因. 然而,这种漂移聚集作用所 引起的藻的迁移量具体能占水体中藻总量的多少还有待于进一步研究. 另外, 不同湖区营养盐的差异也会 大大影响微囊藻在夏、秋季的生长情况. 夏季南部湖区的总溶解性无机氮含量比北部湖区高, 其 TIN/TSP 的 比值 (平均为 199 ) 更是远远大于北部 (平均为 46). $\mathrm{Xu}$ 等 ${ }^{[4]}$ 以梅梁湾为实验场地进行研究后发现太湖藻在 夏季表现出很强的氮限制, 从本研究的结果来看, 太湖南部湖区的情况可能会有所不同, 如果存在营养盐限 制 (当然,也可能不是营养盐限制), 那么相对于 $N$ 限制而言,夏季南部湖区应该更倾向于 $P$ 限制.

绿藻、硅藻、裸藻和隐藻丰度之间都存在极显著的正相关性, 但这四种藻与微囊藻丰度的相关性则不显 著. 这说明绿藻、硅藻、裸藻和隐藻丰度在时空分布上有一定相似性, 而这四种藻与微囊藻丰度则有较大差 异. 其他四种藻的丰度与水温均无显著相关性, 而微囊藻丰度与水温呈极显著正相关, 这可能是因为其更容 
易在温度较高的情况下生长 ${ }^{[10,17]}$.

\section{2 不同湖区无机氮的季节变化及其与浮游植物丰度的关系}

太湖中大部分的无机氮以 $\mathrm{NO}_{3}^{-}-\mathrm{N}$ 的形式存在, 其比例高达 $76 \%$, 这也使得太湖不同湖区各采样点 TIN 的季节变化趋势与 $\mathrm{NO}_{3}^{-}-\mathrm{N}$ 基本相同. $\mathrm{NO}_{3}^{-}-\mathrm{N} 、 \mathrm{NH}_{4}^{+}-\mathrm{N}$ 和 $\mathrm{NO}_{2}^{-}-\mathrm{N}$ 彼此之间呈显著正相关,这说明它们存在一 些共同的污染来源并且不同形态无机氮之间有着彼此转换的关系. 全年总体而言, 太湖北部靠近西北沿岸 的湖区以及竺山湾的 $\mathrm{NH}_{4}^{+}-\mathrm{N}$ 和 $\mathrm{NO}_{2}^{-}-\mathrm{N}$ 浓度要高于其他点位,这可能是因为携带这类污染物的人湖河流主 要从太湖西北部进人湖泊水体 ${ }^{[1]}$ 并且该湖区作为内源的底泥中 $\mathrm{NH}_{4}^{+}-\mathrm{N}$ 浓度也比较高 ${ }^{[6,14]}$. 两湖区的 $\mathrm{NO}_{2}^{-}-\mathrm{N}$ 含量都表现为在春、夏季比较高, 而在秋、冬季比较低, 并且和浮游植物丰度呈显著正相关, 这可能是因为浮 游植物在吸收并还原 $\mathrm{NO}_{3}^{-}-\mathrm{N}$ 的过程会释放 $\mathrm{NO}_{2}^{-}-\mathrm{N}^{[18]} . \mathrm{NO}_{2}^{-}-\mathrm{N}$ 和 $\mathrm{NH}_{4}^{+}-\mathrm{N}$ 的相关性 $(r=0.423, P<0.00001)$ 比其和 $\mathrm{NO}_{3}^{-}-\mathrm{N}$ 的相关性 $(r=0.288, P<0.01)$ 强, 说明有相当一部分 (尤其是竺山湾和西北沿岸区) 的 $\mathrm{NO}_{2}^{-}-\mathrm{N}$ 可能是来自于氨氧化微生物对 $\mathrm{NH}_{4}^{+}-\mathrm{N}$ 的氧化 ${ }^{[19-20]}$.

太湖不同湖区各采样点 TIN 季节变化趋势总体上有着很强的相似性,都表现为春季最高, 夏、秋季有所 降低, 冬季又有所升高. 春季太湖较低的水位、较少的反硝化作用 (因为此时温度较低) 以及较多的氮输人是 导致其高 TIN 的原因 ${ }^{[4,21]}$, 此时的氮输人有很大一部分来自农业化肥等的污染, 其中 $\mathrm{NO}_{3}^{-}-\mathrm{N}$ 所占无机氮的 比例较高 ${ }^{[22]}$. 夏季太湖降雨导致的稀释作用、浮游植物的消耗以及底泥中较高的反硝化作用等都可以使得 水体中的 TIN 浓度下降 ${ }^{[4,8]}$. 虽然太湖北部沉积物中的 $\mathrm{NH}_{4}^{+}-\mathrm{N}$ 和 $\mathrm{NO}_{3}^{-}-\mathrm{N}$ 在夏季有着比其他季节更大的释 放量 ${ }^{[5]}$, 但其所释放的无机氮无法补足其夏季的降低量, 所以水体中的 TIN 在夏季还是急剧下降. 太湖南部 各个采样点在夏季的下降幅度要明显小于北部, 以至于夏季南部湖区的 TIN 含量比北部高, 南部各点的 TIN 到了秋季才急剧下降. 因此, 如果把夏秋季节 TIN 的下降作为一个整体, 南部湖区相对于北部似乎有某种滞 后性.

微囊藻丰度与 $\mathrm{NO}_{3}^{-}-\mathrm{N}$ 浓度以及 TIN/TSP 的比值呈显著负相关. 由此可见, 微囊藻丰度高的地方其 $\mathrm{NO}_{3}^{-}-\mathrm{N}$ 和 TIN/TSP 的比值会比较低. 这一现象在夏、秋季节微囊藻大量暴发的点位可以很明显地看到. 例 如, 秋季梅梁湾的微囊藻丰度 (平均 144 cells/L) 比全湖其他点位都要高, 但其 $\mathrm{NO}_{3}^{-}-\mathrm{N}$ 浓度 (平均 0.33 $\mathrm{mg} / \mathrm{L}$ ) 以及 TIN/TSP 的比值 (平均 14) 却是全湖最低的. Ahn 等 ${ }^{[23]}$ 研究表明, 蓝藻在暴发过程中会吸收大量 氮, 而其对 P 的吸收则相对较少. 因此在这种情况下, 太湖夏、秋季微囊藻暴发的地方会更容易发生氮限制. 绿藻和硅藻丰度都与 $\mathrm{NO}_{3}^{-}-\mathrm{N}$ 呈显著正相关, 并且它们与 TIN/TSP 的比值无显著相关性, 所以它们生长过程 中所面临的限制因子与上述微囊藻的情形会有所差别.

Chl.a/浮游植物的比值与浮游植物总丰度、微囊藻丰度呈极显著负相关, 而与 TIN/TSP 的比值呈极显著 正相关, 这说明当微囊藻大量暴发而 TIN/TSP 下降时, 浮游植物单个细胞内的平均 Chl.a 含量有所下降. 这 可能也是浮游植物总丰度与 Chl. a 相关系数不大 ${ }^{[23]}$ 的原因, 因为当浮游植物大量增加时, 如果其单个细胞 内的 Chl.a 含量相应下降, 则会影响总体 Chl.a 含量和浮游植物总数变化的同步性. Chl.a/浮游植物的下降可 以有两种解释:第一种可能是当浮游植物数量增多时, 其单个细胞的平均体积有所减小, 使得其 Chl.a 含量 也减少. 第二种可能是 TIN/TSP 下降时, 浮游植物单个细胞的 Chl.a 合成量有所降低. 根据 Vrede 等 ${ }^{[24]}$ 的研 究, 生物体的生长速率与其蛋白质合成速率正相关, 从而与细胞中的 $r R N A$ 含量正相关, $\mathrm{rRNA}$ 富含 $\mathrm{P}$ 并且占 据了细胞中 $\mathrm{P}$ 总量的大部分, 所以细胞的生长速率与其 $\mathrm{P}$ 含量有很大关系. 因此, 当环境中的 $\mathrm{P}$ 含量相对丰 富时, 浮游植物细胞会有更高的生长速率, 从而也会消耗更多的 $\mathrm{N}$ 来合成蛋白质, 当 $\mathrm{N}$ 相对缺乏时 (如 TIN/ TSP 较低时), 细胞用于合成 Chl.a (其分子式为 $\mathrm{C}_{55} \mathrm{H}_{72} \mathrm{MgN}_{4} \mathrm{O}_{5}$ ) 的 $\mathrm{N}$ 就会减少,使得细胞的 Chl. $\mathrm{a}$ 合成量有所 减少. 以上推测尚需进一步研究验证.

致谢: 范念文、王易超、周莉、赵琳、吴宁梅等协助完成采样及分析工作,在此对他们表示衷心的感谢.

\section{4 参考文献}

[ 1 ] Qin BQ, Xu PZ, Wu QL et al. Environmental issues of Lake Taihu, China. Hydrobiologia, 2007,581:3-14.

[2] 秦伯强, 王小冬, 汤祥明等. 太湖富营养化与蓝藻水华引起的饮用水危机一一原因与对策. 地球科学进展, 2007, 22 (9) :896-906. 
[ 3 ] Guo L. Doing battle with the green monster of Lake Taihu. Science, 2007,317:1166.

[ 4 ] Xu H, Paerl HW, Qin BQ et al. Nitrogen and phosphorus inputs control phytoplankton growth in eutrophic Lake Taihu, China. Limnol \& Oceanogr, 2010,55:420-432.

[ 5 ] 金相灿,姜 霞,徐玉慧等. 太湖东北部沉积物可溶性氮、磷的季节性变化. 中国环境科学,2006,26(4):409-413.

[ 6 ] 王秋娟,李永峰,姜 霞等. 太湖北部三个湖区各形态氮的空间分布特征. 中国环境科学,2010,30(11):1537-1542.

[ 7 ] 杨 柳,章 铭,刘正文. 太湖春季浮游植物群落对不同形态氮的吸收. 湖泊科学,2011,23(4):605-611.

[ 8 ] McCarthy MJ, Lavrentyev PJ, Yang LY et al. Nitrogen dynamics and microbial food web structure during a summer cyanobacterial bloom in a subtropical, shallow, well-mixed, eutrophic lake (Lake Taihu, China). Hydrobiologia, 2007, 581 : $195-207$.

[ 9 ] Chen YW, Fan CX, Teubner K et al. Changes of nutrients and phytoplankton chlorophyll-a in a large shallow lake, Taihu, China: an 8-year investigation. Hydrobiologia, $2003, \mathbf{5 0 6 / 5 0 7 / 5 0 8 / 5 0 9}(1 / 2 / 3): 273-279$.

[10] Liu X, Lu XH, Chen YW. The effects of temperature and nutrient ratios on Microcystis blooms in Lake Taihu, China: An 11-year investigation. Harmful Algae, 2011,10:337-343.

[11] 孙洁梅,张哲海. 应用冻融法测定湖泊水中 Chl.a 含量. 云南大学学报, 2009,31 (S2) :497-498.

[12］周凤霞,陈剑虹. 淡水微型生物图谱. 北京: 化学工业出版社,2010.

[13] 胡鸿钧,魏印心. 中国淡水藻类:系统、分类及生态. 北京:科学出版社,2006.

[14] Trolle D, Zhu GW, Hamilton D et al. The influence of water quality and sediment geochemistry on the horizontal and vertical distribution of phosphorus and nitrogen in sediments of a large, shallow lake. Hydrobiologia, 2009,627:31-44.

[15] 季 健,孔繁翔,于 洋等. 太湖越冬蓝藻空间分布的初步研究. 湖泊科学, 2009,21(4):490-494.

[16] 杨清心. 太湖水华成因及控制途径初探. 湖泊科学,1996,8(1):67-74.

[17] Paerl HW, Huisman J. Blooms like it hot. Science, 2008,320:57-58.

[18] Lomas MW, Lipschultz F. Forming the primary nitrite maximum: Nitrifiers or phytoplankton? Limnol \& Oceanogr, 2006, 51 ( 5 ) : 2453-2467

[19] 向 燕, 吴宇澄,刘国锋等. 太湖竺山湾沉积物中氨氧化原核生物的垂直分布与多样性. 生态学报, 2010,30(6): 1423-1430.

[20] 王国祥,誉培民,黄宜凯等. 太湖反硝化、硝化、亚硝化及氨化细菌分布及其作用. 应用与环境生物学报, 1998, $5(2): 190-194$.

[21] Gao C, Zhu JG, Zhu JY et al. Nitrogen export from an agriculture watershed in the Taihu Lake area, China. Environ Geochem Health, 2004 ,26 : 199-207.

[22] 叶宏萌,袁旭音,孙西艳等. 太湖北部河网区水体营养元素和形态氮研究. 环境科学与技术, 2009,32(12):52-55.

[23] Ahn CY, Chung AS, Oh HM. Rainfall, phycocyanin, and N: P ratios related to cyanobacterial blooms in a Korean large reservoir. Hydrobiologia, $2002, \mathbf{4 7 4}: 117-124$.

[24] Vrede T, Dobberfuhl DR, Kooijman SALM et al. Fundamental connections among organism C:N:P stoichiometry, macromolecular composition, and growth. Ecology, 2004,85:1217-1229. 